\title{
On the Absence of Moral Goodness in Hobbes's Ethics
}

\author{
Johan Olsthoorn ${ }^{1,2}$ iD
}

Received: 18 September 2019 / Accepted: 6 December 2019 / Published online: 10 February 2020

(c) The Author(s) 2020

\begin{abstract}
This article reassesses Hobbes's place in the history of ethics based on the first systematic analysis of his various classifications of formal goodness. The good was traditionally divided into three: profitably good, pleasurably good, and morally good (bonum honestum). Across his works, Hobbes replaced the last with pulchrum-a decidedly non-moral form of goodness on his account. I argue that Hobbes's dismissal of moral goodness was informed by his hedonist conception of the good and accompanied by reinterpretations of right reason and natural law. By dispensing moral goodness and insisting on the hedonist and relational nature of the good, Hobbes moreover recast and rendered more urgent the question of why we should be moral. Hobbes is commonly thought to have raised this question so starkly because of his general insensitivity to the demands of justice. My analysis suggests that it may also, or rather, have been due to his restrictive conception of the good. A comparison with other moral philosophers from the period-including Suárez, Gassendi, Locke, and Pufendorf-indicates how unusual Hobbes's jettisoning of moral goodness was.
\end{abstract}

Keywords Thomas Hobbes · Moral goodness · Natural law · Ethical hedonism - The right and the good $\cdot$ History of ethics

\section{Introduction}

Existing discussions of Hobbes's theory of the good are by and large confined to scrutinizing the ontological status of moral properties (what does the property of goodness consists in? what makes something good?) and their semantics and psychological underpinnings (what does 'good' mean? how to explain everyday usages of evaluative notions?) (Abizadeh 2018a: 141). Much less attention has been paid to

Johan Olsthoorn

j.c.a.olsthoorn@uva.nl; johan.olsthoorn@kuleuven.be

1 Dept. of Political Science, University of Amsterdam, PO box 15578, 1001 NB Amsterdam, The Netherlands

2 Institute of Philosophy, KU Leuven, Andreas Vesaliusstraat 2, 3000 Leuven, Belgium 
Hobbes's classifications of formal goodness, found in various iterations across his works (EL 7.3; L 6.8; DH 11.5; LL 6.8). Correcting this hiatus, this paper shows how Hobbes subverted the received tripartite division of formal goodness-between profitably good, pleasurably good, and morally good. Moral goodness (bonum honestum) is strikingly absent in each of Hobbes's typologies. (Two sets of apparent textual anomalies can, I show, be explained away). The term is replaced by 'pulchrum', which he took to mean "that, which by some apparent signes promiseth Good" (L 6.8). Hobbes retained the classical counterpart of the bonum honestum-'turpe' (traditionally: moral evil)_but reinterpreted it along non-moral lines to make it chime with his hedonism about the good.

Dissecting Hobbes's typologies of formal goodness is not just of interest in its own right. It also allows us to assess from a novel perspective the character of his natural law theory and his place in the history of ethics. I argue that Hobbes's dismissal of moral goodness logically necessitated reinterpretations of right reason and of the status of natural law. The moral virtues prescribed by natural law (i.e. by the dictates of right reason) are merely profitably good on Hobbes's account, as socially necessary means for achieving the ends of self-preservation and a contented life. My analysis thus bolsters the 'prudentialist' reading of Hobbes's natural law theory. On this interpretation, the laws of nature articulate "prudential reasons centred on the agent's own good", or felicity (Abizadeh 2018a: 110). ${ }^{1}$

This paper situates Hobbes within the long-standing debate, shaped by Sidgwick (1838-1900), on supposed character differences between ancient ethics and modern moral philosophy. The ancient conception of ethics, Sidgwick argued, conceived of the right as a form of goodness: "Virtue or Right action is commonly regarded as only a species of the Good" (1981: 105-106). Sidgwick did not claim that the ancients lacked the deontic notion of the right (and concomitant ideas like 'ought'

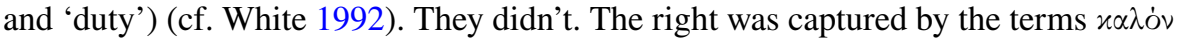
in Greek and 'honestum' in Latin (usually translated as morally right, virtuous, honourable, or noble). His view is rather that deontic notions figure differently in modern moral philosophy than in ancient eudaimonist theories, as being in the latter normatively subservient to happiness (eudaimonia - the agent's overall goal in life). Sidgwick took the ancient eudaimonists to be rational egoists, holding that the only rational ground for action is the agent's own good. "[I]t was assumed on all sides that a rational individual would make the pursuit of his own good his supreme aim: the controverted question was whether this Good was rightly conceived as Pleasure or Virtue or any tertium quid [e.g. knowledge]" (Sidgwick 1981: 92). Eudaimonist ethics would thus presuppose "an inseparable union of the conceptions of Virtue and Interest in the single notion of Good" (Sidgwick 1988: 26). For moderns, moral virtue and individual happiness no longer naturally converge in the same normative standard. The right and the good have become two essentially distinct and

\footnotetext{
1 The reciprocity interpretation of Hobbes's moral philosophy, advanced by Lloyd (2009), is currently the main competitor to the prudentialist reading.
} 
potentially conflicting normative principles-what Sidgwick called 'the dualism of practical reason'. ${ }^{2}$

Sidgwick's reconstruction of the history of ethics has not gone uncontested. ${ }^{3}$ Annas (1995: 243) has countered that the ancient 'monism of practical reason' must be interpreted in the opposite manner: "the missing element" in ancient ethics is in her view prudential reasoning. "[T] here was no constant assumption within ancient ethical theory that prudential reasoning is as authoritative as, or more so than, moral reasoning" (1995: 256). My reconstruction of Hobbes's account of goodness supports her rival understanding of character differences between ancient and modern moral theory. How easily we can explain the normativity of morality by appeal to the agent's good depends, I suggest, on how we interpret that good. My contention is that Hobbes's denial that moral goodness is a species of the good, informed by his restrictive hedonist conception of goodness, recast and rendered more urgent the question of why we should be moral by restating it as 'what do we gain from it?'. The ancient eudaimonists regarded becoming a person habituated to reasoning from a moral point of view (i.e. to treating virtue as an end in itself) as necessary or sufficient for happiness. For Hobbes, by contrast, enacting the virtues prescribed by natural law is merely instrumentally good, insofar as it produces the social conditions necessary for achieving a contented life.

The paper unfolds as follows. Section 2 gives a brief overview of pre-Hobbesian typologies of formal goodness, from Aristotle to Suárez. Section 3 scrutinizes Hobbes's neglected classifications of value. My analysis confirms, with some qualifications, that Hobbes "leaves no room" for the bonum honestum (Irwin 2008: 114). Section 4 discusses an unparalleled passage in the Questions Concerning Liberty, Necessity, and Chance where Hobbes declared, in response to Bramhall, that "moral goodness is the conformity of an action with right reason" (EW 5: 193). Contextualizing this response within seventeenth-century discussions of natural and moral goodness reveals how idiosyncratic Hobbes's accounts of goodness and right reason are (Sect. 5). Section 6 concludes with some suggestions of what my analysis might mean for Hobbes's place within a Sidgwickean history of ethics.

\section{Moral Goodness Before Hobbes}

When Hobbes started pondering the nature of the good, it had long been routine to make two tripartite divisions of the good: one material and one formal. As Hobbes's long-time interlocutor Bramhall (1594-1663) put it, the good can be divided "either subjectively, into the goods of the mind, the goods of the body, and the goods of fortune. Or formally, into bonum honestum, utile \& delectabile, or honestly good, profitably good, and delightfully good" (1657: 200). My concern here is with the formal

\footnotetext{
${ }^{2}$ For an overview of different ways in which the dualism between morality and self-interest is understood in contemporary ethical theory, see Slote (2010).

${ }^{3}$ For a defense, see Larmore (1996). For a collection of revisionist studies in ancient ethics, see Engstrom and Whiting (1996).
} 
classification of goodness. This threefold division is usually associated with the Stoics, though it can be traced back to Aristotle: "There being three objects of choice and three of avoidance, the noble [ $x \alpha \lambda$ oü], the advantageous, the pleasant, and their

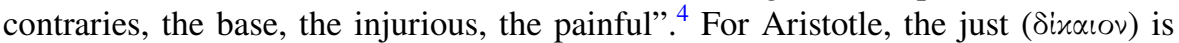
noble ( $x \alpha \lambda \dot{o} v) .^{5}$ By the time of Augustine (354-430), "the Stoics' threefold scheme of classification of goods - the 'pleasant' (delectabile), the 'useful' (utile) and the 'right' (honestum) — had become something of a commonplace" (Markus 1967: 389).

Aristotle and the Stoics invoked a distinct and non-derivative kind of goodness ( $x \alpha \lambda$ ò, honestum) to explain the value of moral virtue. Diogenes Laertius (2018: VII.127) described the Stoic position as follows: "And virtue is worth choosing for its own sake". Cicero (2001: II.45) concurred: "by 'moral', then, I mean that which can justly be esteemed on its own account, independently of any utility, and of any reward or profit that may accrue". While thus contrasting moral rightness with selfadvantage, Cicero insisted that on proper reflection the two coincide. ${ }^{6}$ Moral goodness was regarded as disinterested, in the sense that its content (what it requires) is not determined by reference to the agent's interests. The disinterested nature of virtue is compatible with eudaimonism: pursuing the bonum honestum conduces to the agent's happiness, since virtue is necessary to or constitutive of a flourishing life. ${ }^{7}$ The Stoics held that the honestum is the only true good: "the only thing one is unqualifiedly better off for having" (Frede 1999: 86). Other ancients, including Aristotle, recognized bodily and external goods as well, while insisting that virtue (included in goods relating to the soul) is of prime importance. ${ }^{8}$ For the Epicureans, the highest good is pleasure (understood idiosyncratically as freedom from bodily and mental pains). Yet they agreed that virtue is inseparable from happiness, since vice inevitably troubles the mind (Epicurus 1994: 31-32).

The tripartite division of formal goodness recurs in Aquinas (1225-1274). He answered the question "whether goodness is rightly divided into the virtuous, the useful and the pleasant?" in the affirmative with respect to human goodness. ${ }^{9}$ Aquinas stressed that the three forms of goodness capture distinct ways in which things can be good: "the honest concurs in the same subject with the useful and the pleasant, but it differs from them in aspect". ${ }^{10}$ Treating a neighbour kindly, for

\footnotetext{
4 Aristotle (2000): II.3 (1104b30). Cf. Aristotle (1960): I.13 (105a27-28). The material division, too, is peripatetic in origin: Aristotle (2000): I.8 (1098b10-15).

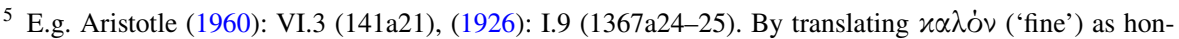
estum, Albert and Aquinas managed to connect Aristotle's value theory with Stoic ethics (Irwin 2007: 607-608).

6 E.g. Cicero (1991) III.50-96, (2001): II.44-85; Ambrose (2002): I.27-28, II.22-9. The opposition is discussed in Striker (1996): 169-182.

7 The eudaimonist presuppositions of Stoic and Epicurean ethics are nicely brought out by (Annas 1993). The Cyrenaic philosophers are commonly seen as having advanced the only non-eudaimonist Greek ethical theory (Annas 1993: 227-236) — though Tsouna-McKirahan (2002) argues that even they were eudaimonists.

${ }^{8}$ E.g. Aristotle (2000): I.8, VII.13; Cicero (2001): II.68.

9 Aquinas, Summa Theologica, I q.5 a.6.

10 Aquinas, Summa Theologica, II-II q.145 a.3.
} 
example, can be good in three distinct respects simultaneously: as an act of virtue, as bringing pleasure to the well-doing agent, and as facilitating the functioning of one's homeowner association. Suárez (1548-1617) adopted the threefold division in both De Legibus (2015: II.11.5) and the Disputationes Metaphysicae (Irwin 2003: 350, 2008: 31-35). The latter text links the right and the pleasurable to distinct psychological capacities (reason and sensation). "According to everyone's view... good that in itself is agreeable to rational nature as such is called bonum honestum", whereas "pleasurable good is nothing other than good having agreeability with sensible nature". "Useful good", in turn, is "the good that is apt and accommodated to an intended end"-whether virtue or pleasure (Suárez 2016: X.1.12). By defining bonum honestum in terms of appropriateness to rational nature, Suárez emphasized its status as a distinctly human good.

For Aquinas and Suárez, the moral good is that part of the individual's good that is common to all human beings (Irwin 2007: 616-619, 2008: 66f). They conceived of the common good as a non-competitive good, pursuable without detriment to others. That morally virtuous actions are thus conducive to all, including to the agent herself, had already been argued by Aristotle (2000: IX.8 [1169a8-11]): "And if everyone strives for what is noble and strains to do the noblest actions, everything will be as it should be for the common interest, and individually each will have the greatest goods, since such is virtue" (Annas 1989). Darwall (2012: 304) concludes: "Suarez and Aquinas both hold that honestas provides no non-eudaemonist ground for action, but is instead a distinctive kind of intrinsic benefit (honestum bonum)".

This brief overview evinces how we are to understand Sidgwick's contention that pre-modern ethics presupposed "an inseparable union of the conceptions of Virtue and Interest in the single notion of Good" (1988: 26). Performing morally right actions, the ancient eudaimonists insisted, conduces to the agent's flourishing and is in that sense part of their overall good. Yet which actions are morally right or virtuous was specified independently from that happiness. Hobbes, we will see, agreed that observing the moral virtues prescribed by natural law is necessary for attaining a contented life. Yet, dismissing moral goodness, he explained the goodness of these virtues themselves through their usefulness to the agent's self-preservation and felicity.

\section{Classifications of Formal Goodness in Hobbes}

This section and the next turn to Hobbes's neglected typologies of value-scholars have shown vastly more interest in examining the ontological status of normative properties than in exploring his typologies of the good. ${ }^{11}$ Terence Irwin is one of the few commentators to have discussed Hobbes's classifications of formal goodness at any length. My analysis confirms his conclusion that "Hobbes does not recognize the

\footnotetext{
11 Notwithstanding its title, Ackerman (1976) contains no discussion of these typologies. It focuses instead on the morality vs expedience of natural law. Ackerman's analysis suffers from multiple conflations, including of justice with morality, and of authorization with alienation of right.
} 
honestum as an aspect of morality distinct from the pleasant and the useful" (2008: 137) —albeit with some qualifications. The honestum does pop up in the Latin texts and in his exchanges with Bishop Bramhall; moreover, we shall see that some of the conceptual space traditionally occupied by the honestum is taken over by the 'just'. Creatively reinterpreting traditional concepts and commonplaces is one of Hobbes's trademarks. The honestum, when mentioned by Hobbes, shared this fate.

Classifications of value are found in Hobbes's 1640 Elements, 1651 English and 1668 Latin Leviathan, and 1658 De Homine. Though generally tripartite too, Hobbes's divisions of formal goodness differ markedly from the traditional contrast between the useful, the pleasant, and the honestum. Most significantly, the honestum is replaced by pulchrum-signalling good to come. Take Leviathan:

"So that of Good there be three kinds; [1] Good in the Promise, that is Pulchrum; [2] Good in Effect, as the end desired, which is called Jucundum, Delightfull; and [3] Good as the Means, which is called Utile, Profitable" (L 6.8).

Interestingly, the three corresponding evils are the traditional ones: "For [1] Evill, in Promise, is that they call Turpe; [2] Evil in Effect, and End, is Molestum, Unpleasant, Troublesome; and [3] Evill in the Means, Inutile, Unprofitable, Hurtfull' (L 6.8). Turpe, the traditional opposite of honestum, normally means 'moral evil' (Irwin 2007: 603-604). As argued below, one remarkable feature of Hobbes's account is that it turns turpe into a non-moral notion.

The classification in De Homine is less evidently modelled on the received tripartite division. Instead of reminding the reader that the good is threefold, Hobbes proclaimed the names of good and evil to be equivocal (DH 11.5). The text proceeds to differentiate 'pleasing' on the one hand from 'pulchrum', and on the other from 'profitable':

"... the same thing that, as desired, is said to be good [bona], is said to be pleasing [jucunda] as acquired; the thing that, as desired, is said to be good [bona], is said to be pulchrum when contemplated... Furthermore, the thing that, when desired, is called good, is, if desired for its own sake, called pleasing [jucunda]; and if for some other thing, it is called useful [utilis]" (DH $11.5) .^{12}$

The passage clearly brings out the aspectual nature of formal goodness: they express distinct ways in which things can be called good. The same thing can be 'good' in all three respects. Wisdom, for instance, is useful because "protection is to be had from it", "pulchrum because it is difficult to acquire", and "desirable for its own sake" because it is pleasing (DH 11.8). The block-quote above depicts pulchrum as 'a good of contemplation' rather than as 'good in the promise'. The two ideas are interlinked. Across his works, Hobbes distinguished pleasures of sense from pleasures of the mind. The former are on his account pleasures of satisfaction stemming

\footnotetext{
12 Hobbes proceeded to mention another opposition, between real and apparent good, which falls beyond the tripartite division of formal goodness (cf. EL 7.8; AW 30.25; L 6.57).
} 
from present sensations, whereas the latter are anticipatory pleasures arising "from the Expectation, that proceeds from foresight of the End, or Consequence of things" (L 6.12). ${ }^{13}$ Pleasures of the mind are nonetheless present joys: the pleasures produced here and now by imagining future satisfaction (EL 8.2).

When translating Leviathan into Latin a decade later, Hobbes again emphasized the tripartite division of formal goodness:

"So that of Good there be three kinds, [1] one in the promise, which is 'pulchritude'; [2] the second in the thing, and it is called 'goodness' [Bonitas]; [3] the third in the end, which is 'delight' [Iucunditas]. Moreover, [3a] the good which, in the end, is called 'delightful', is called [3b] 'profitable' [Utile] in the means. Similarly evil [Malum] as promise is called 'turpe', and in the end it is called 'unpleasant' [Molestum]” (LL 6.8).

Compared to the English Leviathan, the passage adds the enigmatic 'good in the thing' as a separate form of goodness. 'Good in the thing' need not signify some mind-independent form of goodness. The phrase is more plausibly understood in light of a distinction found in Elements: "And as we call good and evil the things that please and displease; so call we goodness and badness, the qualities or powers whereby they do it" (EL 7.3). Herbs, for instance, are pleasing and called 'good' insofar as they are nourishing; displeasing and judged 'bad' insofar as they are poisonous (EW 5: 192). 'Badness' would then be used to signify that quality or power that makes some herb displeasing to us-e.g. its poisonous nature.

Each of Hobbes's classifications of value opposes turpe with pulchrum, rather than with honestum. ${ }^{14}$ Pulchrum and turpe, Hobbes declared, have no English equivalents: their "significations approach to those of Good and Evill; but are not precisely the same". Pulchrum "signifies that, which by some apparent signes promiseth Good"; turpe "that, which promiseth Evil" (L 6.8). Anything we imagine to bode well we call 'pulchrum' as "pulchritudo is that quality in an object that makes one expect good from it" (DH 11.5). According to Elements, 'pulchritudo' refers to "the signs of that goodness"-i.e. of that power or quality by which a thing pleases us (EL 7.3). An insertion in Hobbes's hand to the manuscript of Leviathan captures the same idea more eloquently: "the lustre and glosse of some ability to do Good" (L 6.8n). Hobbes subsumed various thick evaluative terms under pulchrum, including beauty [formosum], gallantness, comeliness [decorum], and amiability [iucun$d u m]$. English terms denoting the turpe include foul, deformed, ugly, base, and nauseous (L 6.8). These translations are technically correct, if incomplete in omitting 'dishonest'.

\footnotetext{
13 Also e.g. EL 7.9; DCv 1.2; AW 30.23; cf. DH 11.1. Abizadeh (2018a: 148-164).

14 The juxtaposition of turpe with pulchrum is also found in the mid-1630s Short Tract (discovered amidst the Hobbes manuscripts at Chatsworth and appended to Tönnies' edition of Elements), albeit with meanings that differ from those found in Hobbes's works: "Pulchrum is the species of Good. For whatsoever is Bonum is Pulchrum, and whatsoever is Pulchrum is Bonum; but it is called Bonum, as it attracteth, and Pulchrum, as it pleaseth. Turpe is the Species of Malum" (Tönnies 1969: 209). The passage can be ignored: the Short Tract is nowadays regarded as authored by Robert Payne (Raylor 2001; Malcolm 2002: 104-139).
} 
What does it mean for something to be a sign or indication of good to come? And how exactly does pulchrum differ from the other forms of goodness (pleasurably good and profitably good)? The term 'good', Hobbes contended, is equivocal in English. It can denote the quality of being useful; of pleasing presently; or of promising to please or be useful in the future. The Latin term pulchrum captures that last sense of 'good', whence things are called "pulchrum when contemplated" (DH 11.5). More precisely, we call things, persons, or actions 'pulchrum' in virtue of their features that make us expect future good from them. For instance, to be praised is pulchrum, because people are generally praised for their eminence; and being eminent, in turn, makes it easier to obtain goods in the future (DH 11.13). Signs of extraordinary power are pulchrum for the same reason. Observe that being praised is pulchrum not because it is a means to obtain some good, but rather because it indicates a quality or power the possession of which is associated with future goods. Judging something to be 'pulchrum' involves a judgment about our own powers, too. We regard things as 'pulchrum' only insofar as we believe ourselves capable of securing the good promised: "whosever therefore expecteth pleasure to come, must conceive withal some power in himself by which the same may be attained" (EL 8.3).

Philosophers today distinguish between intrinsic and extrinsic value on the one hand, and instrumental and non-instrumental value on the other (Korsgaard 1983; Rabinowicz and Rønnow-Rasmussen 2000). The first opposition concerns the way things have value. Has $x$ value of itself or does its value derive from some source extrinsic to itself? ${ }^{15}$ The second contrast captures a difference in the way we value things: whether as an end in itself (non-instrumentally) or for the sake of something else (instrumentally). Anything valued as an end is valued for its own sake. Things valued for their own sake need not have intrinsic value. Hobbes's distinction between the 'delightful' and the 'profitable' maps onto the instrumental/non-instrumental contrast. For Hobbes held that whatever is desired for its own sake is called 'pleasing'. ${ }^{16}$ This insistence is significant by omission: Aristotle had noted that both x $\alpha$ óv and pleasure are "lovable as ends". ${ }^{17}$ As Abizadeh (2018a: 141) argues, for Hobbes pleasure has intrinsic value, as the highest good for him is felicity understood as continual delight in anticipatory pleasures. ${ }^{18}$ Pulchrum expresses a third way in which we value things. We can value things, not only as a means or as an end, but also in virtue of them signalling goods to come.

Hobbes's description of pulchrum as 'good in the promise' is untraditional. However, pulchrum happened to have been one of the two terms traditionally used to

\footnotetext{
15 Intrinsic value, in turn, can be understood in different ways. On the account of G.E. Moore, the intrinsic value of $x$ depends exclusively on intrinsic properties of $x ; x$ thus retains its value in isolation. On Kant's account, $x$ has intrinsic value if and only if it is unconditionally (unqualifiedly) good: regardless of what it effects or accomplishes. Bradley (2006); cf. Kagan (1998). For a discussion of intrinsic value in the context of ancient ethics, see Kraut (2010).

16 DH 11.8: "Etiam appetibile est per se, id est, jucundum". Also DH 11.5.

17 Aristotle (2000): VIII.2 (1155b20).

18 AW 38.8; cf. EL 7.7; L 6.58; DH 11.15.
} 
translate the Greek $x \alpha \lambda$ ò ('fine')—the other being 'honestum'. ${ }^{19}$ Pulchrum means 'beautiful'; as a translation of $x \alpha \lambda$ ' $v$, it is better rendered 'admirable' or 'noble'. ${ }^{20}$ Like the honestum, the pulchrum was traditionally regarded as good and choiceworthy of itself. This is not the case for Hobbes. De Homine's enumeration of things that are pulchrum is diverse: useful inventions, self-confidence, contempt for riches, receiving public praise (DH 11.13). Each is valued as pulchrum insofar as they are reliably linked with procuring worldly felicity.

Hobbes employed both pulchrum and turpe in a decidedly non-moral sense. ${ }^{21}$ This is particularly noteworthy with respect to turpe. Displaying excessive courage in dangerous circumstances Hobbes deemed 'turpe' because "it is stupidity". Signs of ignorance are turpe since knowledge is power. So is generosity to enemies, as it signifies need. On the other hand, "new inventions, if useful, are pulchrum; for they are a sign of extraordinary power" (DH 11.13). ${ }^{22}$ These examples suggest that the kinds of good and evil 'promised' by pulchrum and turpe are the pleasant and useful. Things are called 'pulchrum' insofar as they signal future pleasure or utility; 'turpe' insofar as they spell trouble. The two do not track an entirely different kind of value - moral goodness or evil. Hobbes's general typologies of the good thus support the conclusion that he leaves no place for the honestum.

Bramhall even accused Hobbes of reducing all forms of goodness to the pleasurable:

"That which is honestly good, is desirable in it self, and as it is such. That which is profitably good, is that which is to be desired, as conducing to the obtaining of some other good. Thirdly, delightfully good is that pleasure which doth arise from the obtaining of the other goods desired. But he [Hobbes] hath quite cashiered the two former sorts of good, That which is honestly good, and that which is profitably good; and acknowledgeth onely that which is delightfully good, or that which pleaseth him or me." (1657: 200)

All three forms of goodness recognized by Hobbes-pulchrum, jucundum, and utile-ultimately reduce, Bramhall contended, rightly I think, to the goodness of pleasure. Things can be good by producing pleasures of satisfaction (equated with pleasures of sense) or by producing anticipatory pleasures (pleasures of mind). Hobbes called the former 'delightfully good', the latter 'pulchrum'. The two express different kinds of pleasures - of the senses and of the mind. The only other kind of good recognized by Hobbes - the profitably good-is valued as a means to procure

\footnotetext{
19 Irwin (2007: 599-608). Cf. Shaftesbury (2000): 353n, 415n: "This is the honestum, the pulchrum, $\tau$ ó $\varkappa \alpha \lambda \dot{\nu} \nu$, on which our author lays the stress of virtue"; Mandeville (1924: 373): "the pulchrum \& honestum, the $\tau$ o $\varkappa \alpha \lambda$ óv that the Ancients have talk'd of so much".

20 The associations $\varkappa \alpha \lambda$ ó $\nu$ has with beauty and orderliness has led some to detect an aesthetic component in Aristotle's conception of virtue (Rogers 1993; cf. Irwin 2010).

21 Even on his own deflationary conception of 'moral' as "what is Good, and Evill, in the conversation [i.e. interaction], and Society of man-kind" (L 15.40).

22 Compare the lists of honourable signs in EL 8.5-6 and L 10 (Latin: honorare). Strauss (1952: 35-7, 49) argues that the lists are inspired by Aristotle's Rhetoric, a work which Hobbes praised and translated. In corresponding passages Aristotle speaks about $\varkappa \alpha \lambda$ óv.
} 
something pleasurable (in either of the above forms). The value of these forms of goodness can thus ultimately by explained by pleasure.

Hobbes's value theory has affinities with the Epicurean one. ${ }^{23}$ For Epicurus, pleasure is the highest good: "everything else is a means to it, while it is not itself a means to anything" (Cicero 2001: I.29). Like Hobbes, Epicurus emphasized the mental pleasures produced by expectations of good things to come (e.g. Laertius 2018: II.89; Cicero 1927: III.41). Epicurus (1994: 30) held that "every pleasure is a good thing... but not every [pleasure] is to be chosen" as sometimes indulging in pleasures later causes greater trouble. Hobbes likewise regarded sinning 'good' insofar as it is pleasurable, though bad insofar as this pleasure is outweighed by "the bitterness of punishment" inseparably annexed to it (EL 7.8). Albeit for diverging reasons, both Epicurus (1994: 30) and Hobbes valued moral conduct only instrumentally, as socially necessary means to felicity. These commonalities notwithstanding, Hobbes rejected the Epicurean idea of katastematic pleasures, consisting in the absence of bodily and mental pains (aponia and ataraxia). Indeed, he reiterated the Cyrenaic charge that Epicurean felicity- "perpetuall Tranquillity of mind"-is the condition of a person dead or asleep, for whom all desire has ceased (L 6.58; L 11.1; cf. Laertius 2018: II.89).

My analysis of Hobbes's classifications of goodness suggests that he was a hedonist about the good. All goodness ultimately refers to pleasure, in two ways. First, whatever is desired for its own sake (i.e. is sought as an end) is called pleasing (DH 11.5, 11.8). Second, and more generally, whatever triggers desire is experienced as pleasant. Leviathan defines "DELIGHT" as the "appearance" of appetite, and "TROUBLE OF MIND" as the mental sensation of aversion (L 6.9-10). Hence, "whatever seems Good is pleasant" (DCv 1.2). Hobbes believed that "the proper object of every mans Will, is some Good to himself" (L 25.2). The intentional object of a desire need not be pleasure (jucundum) itself, however. It can also be another type of formal goodness: the useful or the pulchrum. After all, things can be desired not for their own sake, but as a means to some end; and those things appear good to us qua means to some end. Since pleasure is, in addition, the phenomenal correlate of desire, whatever we desire as profitably good or as pulchrum pleases us. While the intentional object of our desire need not be pleasure itself, as the mental sensation of desire, pleasure presumably has some motivational force. Hobbes was thus arguably committed to a weak form of psychological hedonism (Abizadeh 2018a: 146-147).

\footnotetext{
${ }^{23}$ On Epicurus's hedonist theory of value, see e.g. Striker (1996: 196-208), Cooper (1998: 485-514) and Woolf (2004).
} 


\section{Two Textual Anomalies}

Two sets of textual objections militate against the conclusion that Hobbes left no room for the bonum honestum. ${ }^{24}$ First, the terms honestum/honestas do occur in his Latin works. The juxtaposition of turpe with honestum in the poem De Mirabilibus Pecci, composed in the 1620 s, can be discounted as juvenile. ${ }^{25}$ Yet the opposition recurs in De Cive, albeit not in the context of expositions of goodness. ${ }^{26}$ More significantly, the Latin Leviathan lists, surprisingly and without further explanation, honestum and inhonestum as species of pulchrum and turpe (LL 6.8). The terms translate the English 'honourable' and 'base'. ${ }^{27}$ Irwin's claim that Leviathan's typology of the good excludes honestum thus holds true only for the English edition. However, even in the Latin Leviathan, honestum is not a basic form of goodness but a species of pulchrum.

What does it mean for honestum to be 'good in the promise'? A possible answer is found in De Homine, which similarly mentions 'honestas' as a species of 'pulchrum'. Having again defined pulchritudo as an indication of future good, Hobbes introduced a new distinction between two types of pulchrum. As considered in actions, pulchrum is called 'honestas'; when dwelling in form, 'forma' ('beauty'). ${ }^{28}$ The underlying idea is apparently as follows. Actions are called 'pulchrum' in virtue of indicating future goodness. The general name for such actions is 'honestas'. Honestas traditionally meant 'virtue', 'duty', or 'right action'; the bonum honestum depicted the kind of good honestas targets. So perhaps Hobbes meant that virtuous actions are pulchrum insofar as they signal future good to the onlooker. If so, then still nothing suggests that such actions track a special form of goodness ('the bonum honestum'). Indeed, Hobbes provided a strikingly non-moral gloss on honestas as a sign of goodness in actions. Ignoring a favour-seeker, for instance, is pulchrum (honestas), "for it is an indication of self-confidence" (DH 11.13). I conclude that Hobbes's inclusion of honestas and honestum in his Latin works accords with Irwin's contention: these passages neither present the honestum as a basic, nor as a distinctly moral form of goodness.

The second textual challenge is more complicated. In his dispute with Bishop Bramhall, Hobbes verbally endorsed the former's distinction between natural and moral goodness. Working within the traditional threefold division of formal goodness, Bramhall identified moral goodness with "what is honest", and natural

\footnotetext{
24 An ostensible third objection is found in The Art of Rhetoric Plainly Set Forth, included in Molesworth's edition of Hobbes's works (EW 6: 511-536). The text gives the following example of a synecdoche: "So righteousness, a member of goodness, is put for all goodness" (EW 6: 518). The passage should be ignored: The Art of Rhetoric Plainly Set Forth was not written by Hobbes. The text was included in a 1651 reprint of four treatises on rhetoric, only one of which was by Hobbes: his translation of Aristotle's Rhetoric entitled A Briefe of the Art of Rhetorique (1637). Raylor (2018: 3, 285-286).

25 OL 5: 327, 401. On the poem, see Raylor (2018: 94-126).

26 DCv P.18, 6.9, 10.11, 12.1, 12.12, 15.11 .

27 See also LL 21.14, where Hobbes equates inhonestum with turpitudo ("turpiter, vel inhonestè").

28 DH 11.5: "Quae, cum in actionibus spectatur, dicitur honestas; quando in forma consistit, appellatur forma". Cf. L 10.13; LL 10.14: "Forma potentia est; est enim Boni promissio".
} 
goodness with "what is profitable or delightful" (EW 5: 171; also Bramhall 1657: 200). "The moral goodness of an action is the conformity of it with right reason. The moral evil of an action is the deformity of it, and the alienation of it from right reason" (EW 5: 170-171). Bramhall faulted Hobbes for failing to observe the distinction between moral and natural goodness. "To praise anything morally", he wrote, "is to say, it is morally good, that is conformable to right reason" (EW 5: 171). In response, Hobbes advanced the unparalleled and possibly spurious claim that conformity with law makes an action morally good: "It is the law from whence proceeds the difference between the moral and the natural goodness: so that it is well enough said by him [Bramhall], that 'moral goodness is the conformity of an action with right reason"" (EW 5: 193).

If this response is genuine, then Hobbes recognized the bonum honestum after all. His verbal endorsement of moral goodness- "a good that is not assessed by reference to the agent" (Irwin 2008: 114)—fits badly with his ethics as usually understood. ${ }^{29}$ Perhaps for these reasons, Schneewind (1998: 123) avers that Hobbes here talked about moral and natural good "without attributing much importance to it". Is Hobbes's reply indeed spurious? One reason for thinking so is that the phrase 'moral goodness' occurs nowhere else in Hobbes's corpus. Moreover, the term is mentioned here at the instigation of, and in explicit reply to, an objection from Bramhall. The distinction may well be endorsed for argument's sake alone. ${ }^{30}$ Another reason for thinking so, is that by accepting Bramhall's vocabulary Hobbes aligned himself with an ethical tradition that portrayed the moral good as being: (a) simply or absolutely good (i.e. good without respect to anyone); (b) unconditionally good (good regardless of context); (c) intrinsically valuable (good in itself); and (d) of noninstrumental value (sought for its own sake). Aquinas for instance described 'honesta' as "goods intrinsically [per se] and without qualification [simpliciter], which are desired as ends for their own sake, even when they lead to something else". ${ }^{31}$ Yet Hobbes denied that the moral virtues are good in any of these four senses.

Aristotle (2000: VII.12) had maintained that things can be good in two senses: "good without qualification, and good for somebody". Hobbes only recognized the latter: "one cannot speak of something as being simply good; since whatsoever is good, is good for someone or other" (DH 11.4). "For even the goodness which we attribute to God Almighty, is his goodness to us" (EL 7.3; also EW 5: 210; DH 11.4). The ordinary use of evaluative terms indicates the same: "these words of Good, Evill, and Contemptible, are ever used, with relation to the person that useth them: There being nothing simply and absolutely so" (L 6.7). ${ }^{32}$ Since people have

\footnotetext{
29 While commentators continue to dispute whether Hobbes's moral philosophy includes impartial elements, he is usually and plausibly read as grounding natural law in considerations of enlightened selfinterest. The seminal deontological reading is Taylor (1938). For a more recent discussion, see Harvey (2004).

${ }^{30}$ Which could pose a problem to interpretations drawing on the notion of moral goodness developed in this passage (e.g. Gauthier 1982: 22-23, 2001: 270; Lukac de Stier 2002: 95).

31 Aquinas, Sententiarum Lombardiensis, II d.21 q.1 a.3c: "bona simpliciter et per se, quae tanquam fines appetuntur sui gratia, etsi in aliud ducant".

32 Also AW 30.24; EW 5: 192. Hobbes rejected 'metaphysical goodness' on the same grounds.
} 
diverging desires and interests, "there must needs be many things that are good to some and evil to others; so that what is good to us is evil to our enemies" (DH 11.4). All value is therefore context-dependent: "Therefore good is said to be relative to person, place, and time... For the nature of good and evil follows from the nature of circumstances" (DH 11.4). Hobbes acknowledged that "there can be a common good... that is, [things] useful to many, or good for the state". It is possible to "talk of a good for everyone, like health: but this way of speaking is relative" (DH 11.4; also AW 30.24). Peace and the means to peace (the moral virtues) are common goods in this relative sense ( $\mathrm{L}$ 15.40). Hobbes nowhere claimed that having virtuous character traits or performing morally right actions is constitutive of the good life. Moral virtues are rather valued instrumentally, as the socially necessary means to achieve peace, self-preservation, and worldly felicity. "For every man is assumed to be naturally after his own good; he seeks Justice only incidentally, for the sake of peace" (DCv 3.21).

Hobbes's hedonistic and relational conception of goodness is incompatible with the honestum as traditionally understood. However, the bonum honestum does not need to be conceptualized as being of non-instrumental and non-relational value. Indeed, two well-known contemporaries of Hobbes reinterpreted moral goodness to make it chime with their hedonist theories of value. The French Epicurean philosopher Pierre Gassendi (1592-1655) subsumed the "Bonum honestum, or honest Good" under the pleasant:

“tho' we commonly reckon three sorts of good things, viz. The Honest [honestum], the Profitable [utile], and the Pleasant [iucundum]: The Pleasant or Pleasurable [iucundum sive voluptatem], which is nothing else but Pleasure it self, is so intermixt with the rest, that it don't seem to be a distinct Species of it self, but part of the common Stock, which renders the others Good and Desirable; as if that which is Honest and Useful, were only to be desired because it is Pleasing and agreeable." (1699: 88, also 82, 93-97)

Performing virtuous actions is good insofar as it brings pleasure to the agent. Virtue produces pleasure indirectly, through public honours. Citing Epicurus, Gassendi defined the Honest as "that which is Glorious and Honourable, by the Vogue and universal Consent of all Mankind" (1699: 96). Honest conduct, being universally approved, tends to bring praise, glory, honour, and renown to the agent. Gassendi explains the goodness involved in justice similarly. "Justice is a kind of Goodness" because it is generally praised as the most excellent virtue-and receiving such praise is pleasurable (1699: 306, also 315).

John Locke (1632-1704) likewise tried to account for moral goodness along hedonist lines. "Things then are Good or Evil, only in reference to Pleasure or Pain" (1975: II.20.2).

\footnotetext{
33 This is the anonymous English translation of François Bernier's abridged French translation of Gassendi's Syntagma Philosophicum. The passage is quoted in Schneewind (2003: 361).
} 
"Morally Good and Evil then, is only the Conformity or Disagreement of our voluntary Actions to some Law, whereby Good and Evil is drawn on us, from the Will and Power of the Law-maker; which Good and Evil, Pleasure or Pain, attending our observance, or breach of the law, by the Decree of the Lawmaker, is that we call Reward and Punishment." (1975: II.28.5) $)^{34}$

The moral good or evil of actions ultimately consists in this: "whether as Duties, or Sins, they are like to procure them happiness, or misery, from the hands of the Almighty" (1975: II.28.8). In short, the honestum is good for Gassendi because virtuous conduct brings this-worldly glory and honour; for Locke, because it procures divine rewards. Both philosophers thus seek to account for moral goodness in terms of pleasure. No such convoluted attempt to reduce the value of moral goodness to pleasure is found in Hobbes. He simply discarded the notion altogether.

\section{Moral Goodness and Right Reason}

Let us quote Hobbes's potentially spurious reply to Bramhall in full:

"It is the law from whence proceeds the difference between the moral and the natural goodness: so that it is well enough said by him, that 'moral goodness is the conformity of an action with right reason'; and better said than meant; for this right reason, which is the law, is no otherwise certainly right than by our making it so by our approbation of it and voluntary subjection to it. For the law-makers are men, and may err, and think that law, which they make, is for the good of the people sometimes when it is not. And yet the actions of subjects, if they be conformable to the law, are morally good, and yet cease not to be naturally good" (EW 5: 193).

The first thing to note is that Hobbes twisted Bramhall's point ("better said than meant") through his idiosyncratic conception of right reason. It was a scholastic commonplace that the moral goodness of actions consists in their conformity with right reason (conceived as a kind of law, in allusion to Cicero 1998: III.33). Yet Hobbes's contemporaries quarrelled over the sense in which right reason is the measure of moral goodness. Naturalists about morality maintained that right reason indicates what is in itself morally good and evil. Voluntarists about morality, by contrast, regarded moral good and evil as logically posterior to right reason: an action is morally good in virtue of voluntarily according with right reason, evil in straying from it.

\footnotetext{
34 Also Locke (1997: 301): "The difference between moral and natural good and evil is only this; that we call that natural good and evil, which, by the natural efficiency of the thing, produces pleasure or pain in us; and that is morally good or evil which, by the intervention of the will of an intelligent free agent, draws pleasure or pain after it, not by any natural consequence, but by the intervention of that power. Thus, drinking to excess, when it produces the headache or sickness, is a natural evil; but as it is a transgression of law, by which a punishment is annexed to it, it is a moral evil."
} 
Suárez and Grotius (1583-1645) were both naturalists about morality. For them, natural law tracks intrinsic moral value (honestum and turpe). According to Suárez, "the natural law prohibits those things that are bad in themselves" while ordering us to do what is intrinsically morally right (2015: II.6.12). The goodness or badness which "dwells" in any human action "in view of its object" consists "in harmony or disharmony with right reason" (2015: II.6.17). Suárez combined naturalism about morality with voluntarism about law and obligation. While the obligation imposed by natural law derives from God's commands and prohibitions, divine legislation does not create moral good and evil. "On the contrary, it necessarily presupposes the existence of a certain righteousness or turpitude in these actions and attaches to them a special obligation derived from divine law" (2015: II.6.11). ${ }^{35}$ Grotius was a naturalist about both morality and moral obligation. He defined natural law as "the Rule and Dictate of Right Reason, shewing the Moral Deformity or Moral Necessity there is in any Act, according to its Suitableness or Unsuitableness to a reasonable Nature" (2005: I.1.10.1). For him, natural law regulates actions that "are in themselves either Obligatory or Unlawful, and [which] must, consequently, be understood to be either commanded or forbid by God himself" (2005: I.1.10.2). Divine legislation is thus not needed to render intrinsically morally right actions obligatory to begin with (Olsthoorn 2019: 58-61).

Dismissing earlier naturalist views, Pufendorf (1632-1694) developed a voluntarist position about both morality and natural law. Not just moral obligation, but also moral good and evil are first introduced by natural law: "no Actions are in themselves Good or Bad, Honest or Vile, till they are made so by some Law" (1729: II.3.4, also I.2.6). Pufendorf followed Hobbes in this regard: "The Desires, and other Passions of man, are in themselves no Sin. No more are the Actions, that proceed from those Passions, till they know a law that forbids them: which till Lawes be made they cannot know" (L 13.10). Locke likewise held that moral good and evil presuppose a law of some kind. "If no law were provided all things and actions would be entirely indifferent and neutral" (1997: 62); "it being their Conformity to, or Disagreement with some Rule, that makes [actions] to be regular or irregular, Good or Bad" (1975: II.28.15).

Locke and Pufendorf combined voluntarism about morality with a sharp distinction between natural and moral goodness (e.g. Pufendorf 1729: I.2.6, II.3.21; Locke 1997: 301). Like Bramhall (EW 5: 171), they subsumed the profitable and the pleasant under 'natural goodness', which does not presuppose law, in contradistinction with moral goodness. Moral goodness, in turn, was reconceptualized to reconcile it with voluntarism about morality. For naturalists like Aquinas, Suárez, and Grotius, natural law orders us to do what is pre-legally right and to avoid what is pre-legally evil. ${ }^{36}$ Voluntarists made moral goodness conceptually posterior to and dependent on natural law: actions are morally good in virtue of voluntarily conforming with natural law. "We call that Action Good morally or in Moral Estimation, which is

\footnotetext{
35 Also e.g. Suárez (2015): II.7.1, II.9.4. Insightful analyses of Súarez's ethics are found in Haakonssen (1996: 16-24) and Irwin (2008: 1-69, 2012).

36 E.g. Aquinas, Summa Theologica, II-I q.94 a.2.
} 
agreeable to the Law, and that Action Evil which is disagreeable" (Pufendorf 1729: I.7.3). "[N]aturally good things, or Advantages", Richard Cumberland (1631-1718) wrote, are distinct from "things Morally Good... [which] are only voluntary actions conformable to some Law, especially, that of Nature" (2005: 515-516). ${ }^{37}$

Bramhall was a naturalist about morality. For him, right reason is the means through which humans partake in God's eternal law. "The law participated, which is the ordination of right reason, instituted for the common good, to show unto man what he ought to do, and what he ought not to do" (EW 5: 137). The divine will is the immutable standard of the honestum:

"The will of God, and the eternal law which is in God himself, is properly the rule and measure of justice. As all goodness, whether natural or moral, is a participation of divine goodness, and all created rectitude is but a participation of divine rectitude, so all laws are but participation of the eternal law from whence they derive their power [i.e. authority]" (EW 5: 136).

Hobbes agreed with Bramhall that right reason constitutes the fundamental evaluative standard. Yet he denied that right reason can be found in the nature of things themselves: "This common measure, some say, is right reason: with whom I should consent, if there were any such thing to be found or known in rerum naturâ" (EL 29.8; also L 6.7). This claim has bewildered some commentators, noting Hobbes's apparent affirmation of the existence of right reason in De Cive. ${ }^{38}$ The puzzle can be explained away as follows.

Suárez had identified two meanings of 'right reason': (1) as the objective rule of natural rectitude; and (2) as a cognitive judgment of practical reason (2015: II.5.1; Irwin 2008: 8). Hobbes jettisoned the first sense and reinterpreted the second. Rather than being an objective normative standard (grounded in the nature of things or in the divine will), right reason for Hobbes consists in correct ratiocination by humans. "By right reason in men's natural state, I mean, not as many do, an infallible Faculty, but the act of reasoning, that is, a man's own true Reasoning about actions of his which may conduce to his advantage or other men's loss" (DCv 2.1n). For Bramhall and Suárez, the dictates of right reason exclusively point out what is morally right and wrong (Fernández-Castañeda 1968). Moral rectitude is, after all, defined as acting in accord with rational nature. Right reason and moral rectitude were tied together, I conjecture, by the scholastic theory of rational, sensible, and nutritive parts of the soul; the former being the part of human nature to which right reason conforms. For Hobbes, rejecting scholastic psychology, right reason in the first instance tracks natural goodness - self-advantage. Indeed, by nature, "jus and utile, right and profit, is the same thing" (EL 14.10; also DCv 1.10). Outside the state, the

\footnotetext{
${ }^{37}$ On early modern interpretations of the distinction between natural and moral goodness, see Schneewind (1987: 128-130, 1998: 110, 123-125).

${ }^{38}$ LeBuffe (2020). On Hobbes's account of right reason more generally, see e.g. Kavka (1983), Barnouw (2008) and Greene (2015).
} 
laws of nature form the true measure of good and evil—and of self-interest—by prescribing the necessary social means for securing self-preservation (L 15.34). ${ }^{39}$

While everyone in reason agrees that the moral virtues are good, Hobbes claimed, in practice evaluative judgments follow each person's shifting passions and desires. Disagreement hence abounds about which actions exactly are instances of moral virtue. "Since, however, good and evil are not the same to all, it happens that the same manners are praised by some and condemned by others, that is, are called good by some, evil by others, virtues by some, vices by others". ${ }^{40}$ The general failure to apply the laws of nature correctly and impartially generates a need for an authoritative public evaluative standard. To forestall conflicts and "for want of a right Reason constituted by Nature", humans "must by their own accord, set up for right Reason, the Reason of some Arbitrator, or Judge" (L 5.3; also EL 29.8). This common evaluative standard is the civil law. "Therefore a common standard for virtues and vices doth not appear except in civil life; this standard cannot... be other than the laws of each and every state" (DH 13.9). ${ }^{41}$ As Bramhall (1657: 199) discovered aghast: "by right reason he understands the arbitrary edicts of an elective Governoour"! ${ }^{42}$

Hobbes's reinterpretation of right reason, as being always the reasoning of someone and as not tracking moral value, in turn transformed the status of natural law qua dictates of right reason. Reasoning about how to conduct oneself among others just is prudential reasoning - in the sense of thinking through what conduces to the agent's ongoing felicity. Natural law becomes a measure of what truly "conduceth to the conservation and defence of themselves" (L 15.41). The prescriptions of natural law take into account the particular characteristics and interests of the agent reasoning. As it happens, the content of natural law is identical for all. This follows from some shared human characteristics, including foremost vulnerability and rough equality of power-not from some intrinsic moral value tracked by natural law. Nothing guarantees that the dictates of natural reason will have the same content for differently constituted agents. Indeed, Hobbes freely acknowledged that different moral standards apply to God. ${ }^{43}$ And if someone were to obtain (nigh) irresistible power, reason would prescribe to her other means about how best to preserve herself amidst multitudes. ${ }^{44}$ Bramhall observed, in shock, that Hobbes "hath left no reall good in the World, but only that which is relatively good". ${ }^{45}$ Real good, in the Bishop's view, is embedded in the nature of things, and not dependent on the agent's contingent interests and powers.

We are now in the position to complete our analysis of Hobbes's reply to Bramhall. In his rejoinder, Hobbes reiterated well-known doctrines of his_-albeit in language taken over, for the occasion, from the Bishop. Consider the following passage:

\footnotetext{
39 E.g. EL 17.14; DCv 2.1; DCv 3.26; DCv 3.29; L 15.40.

${ }^{40} \mathrm{DH}$ 13.8. Also e.g. DCv ED.7; DCv 3.32; L 4.23.

41 Also DCv 12.1; L 29.6-7; L 46.32.

42 Also Bramhall (1995: 154): "he fancieth no reality of any natural justice or honesty, nor any relation to the Law of God or nature, but only to the Laws of the Common-wealth".

43 E.g. EW 5: 103, 115, 212.

44 EL 14.13; DCv 1.14; L 31.5; EW 5: 116, 143, 146.

45 Bramhall (1657: 200); also EW 5: 137; Cumberland (2005: 722).
} 
"All the real good, which we call honest and morally virtuous, is that which is not repugnant to the law, civil or natural; for the law is all the right reason we have, and... is the infallible rule of moral goodness. The reason whereof is this, that because neither mine nor the Bishop's reason is right reason fit to be a rule of our moral actions, we have therefore set up over ourselves a sovereign governor, and agreed that his laws shall be unto us, whatsoever they be, in the place of right reason, to dictate to us what is really good" (EW 5: 194).

The passage expounds a well-known Hobbesian doctrine. Natural law, consisting in correct judgments about which actions and predispositions are conducive to peace, is the true standard of morality. Yet to forestall the moral disagreement rife among miscalculating and passion-driven humans, a sovereign is instituted whose laws serve as the public standard of right reason. The passage is anomalous however in its use of the terms 'moral goodness' and 'real good'. Normally, Hobbes called actions or dispositions in conformity with (right) reason or law 'just' instead. "The names of Just and Injust... signifie the Conformity, or Inconformity to Reason" of either actions or manners (L 15.10). "Lawes are the Rules of Just, and Unjust; nothing being reputed Unjust, that is not contrary to some Law" (L 26.4). "Injustice... is the Inconformity of the Action to the Law" (L 46.31). ${ }^{46}$

The connection between justice and law has well-developed theoretical underpinnings in Hobbes. The natural law precept of justice orders agents to fulfil selfincurred obligations ( $\mathrm{L}$ 15.14). In the duty to perform one's covenants, Hobbes proclaimed, "consisteth the Fountain and Originall of JusticE... the definition of InJustice [being] no other than the not Performance of Covenant" (L 15.2). Breaches of covenant are unjust because they are without right - the right having been previously laid down in the covenant: "the name wrong [iniuria] is applied to an action or a failure to act, because it is without right [sine iure] inasmuch as the party which acted or failed to act had already transferred the right to someone else" ( $\mathrm{DCV} 3.3$; also EL 16.2; L 14.7). The underlying conception of 'just' as consisting in actions performed with right, and 'unjust' as actions without right, is found throughout Hobbes's works. Since citizens have promised in the original covenant to obey the sovereign in all things not contrary to self-preservation, justice indirectly requires them to obey the civil law. Law-abiding actions are thus 'just' only derivatively, in virtue of being performances of covenants. In this respect, Hobbes's conception of justice differs from the voluntarist conception of moral goodness as actions that freely conform with law-and not only because Hobbes employed the language of 'justice' and tethered the justice of actions to civil rather than natural law. While Locke, Pufendorf, and Cumberland defined moral goodness as the voluntary conformity of actions with law, Hobbes linked the idea of 'just actions' to law-abiding conduct indirectly, via performance of covenants.

When Hobbes wrote, in reply to Bramhall, that what "we call honest and morally virtuous, is that which is not repugnant to the law, civil or natural" he was reiterating a position elsewhere cast in terms of justice (EW 5: 194). The distinction between

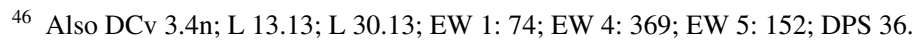


real and apparent good, too, is elsewhere glossed differently. 'Real good' Hobbes interpreted relationally: a thing or action is really good to some agent if and only if it together with all its inseparable long-term consequences contributes overall to the agent's felicity (EL 7.8; AW 30.25; L 6.57; DH 11.5). ${ }^{47}$ This suggests that Hobbes's gloss on 'real good' as 'honest' in his polemical reply to Bramhall is insincere. The same applies to his verbal endorsement of moral goodness. Nowhere else did Hobbes depict the right as a distinct species of the good. Hobbes's reply to Bramhall can be rendered consistent with positions he expounded elsewhere by substituting 'just' for 'real good' and for 'morally good'. I conclude that Hobbes's ethical theory has no place for the idea of moral goodness. ${ }^{48}$

\section{Hobbes's Place in the History of Ethics}

This article has explored the grounds and theoretical implications of the striking absence of moral goodness in Hobbes's ethics. Whether intentionally or not, Hobbes masked this omission by restating that there are three basic forms of good and evil and by replacing honestum with pulchrum - the other Latin term traditionally used to translate $x \alpha \lambda$ ov. Yet he stripped pulchrum and turpe of their moral connotations to bring them in line with his hedonism about the good. His dismissal of moral goodness, I have argued, necessitated reinterpretations of right reason and of the status of natural law. Natural law still prescribes moral virtues-though no longer for their own sake, but as socially necessary means for achieving one's natural good (including foremost self-preservation). In discarding moral goodness altogether, I have suggested, Hobbes stands out among early modern ethicists.

Allow me in conclusion to offer some speculations as to what my analysis might mean for Hobbes's place in the history of ethics. Sidgwick has argued that modern moral philosophy differs from pre-modern ethics in recognizing two independent regulative principles - the right and the good.

“... in Greek moral philosophy generally, but one regulative and governing faculty is recognized under the name of Reason-however the regulation of

\footnotetext{
${ }^{47}$ Real good is hence not mind-independent for Hobbes, as it was for Bramhall and Suárez (2016: X.1.3): "the difference between true good and apparent [good] is this: the apparent good is only imagined and apprehended by the intellect, but the true good subsists in reality itself and is assumed prior to every imagination of the intellect".

48 Hobbes's dismissal of moral goodness had some politically convenient implications for him. Denying that moral value resides in intrinsic properties of the action. It allowed him to claim, first, that the justice of an action or disposition depends exclusively on its conformity to civil law. Since no action is intrinsically right or wrong, civil laws can prescribe or proscribe any action. "[E]very action in its own nature is indifferent. What is just or unjust derives from the right of the ruler" (DCv 12.1; also DCv 16.2). In doing so, the sovereign can sin: civil decrees might transgress natural law, as being detrimental to peace and salus populi (e.g. EL 21.3; EL 28.1; DCv 6.13n; DCv 7.14; L 18.6; L 21.7; L 22.15; L 24.7; EW 5: 178). Yet legal decrees cannot be morally wrong by failing to track intrinsic moral value. Second, this denial allowed Hobbes to claim that justice prescribes different actions to citizens than to sovereigns. Since the justice or injustice of an action depends exclusively on whether it accords or violates a prior agreement, what is unjust for citizens need not be unjust for sovereigns.
} 
Reason may be understood; in the modern ethical view, when it has worked itself clear, there are found to be two-Universal Reason and Egoistic Reason, or Conscience and Self-Love" (Sidgwick 1988: 198). ${ }^{49}$

Pre-moderns regarded ethics "as an inquiry into the nature of the Ultimate End of reasonable human action-the Good or 'true Good' of man" (Sidgwick 1981: 3). The right was conceived in terms of the good: $x \alpha \lambda$ ò and honestum lay a claim on agents as being necessary for, or constitutive of, a flourishing life. Moderns, by contrast, conceive of ethics as an investigation of "the general rules of Duty or Right Action... viewed as absolutely binding on every man" (Sidgwick 1988: 6, also 1981: 2-3). The right, Sidgwick contended, has become normatively fundamental: morality's demands are seen as binding irrespective of their effect on the overall happiness of the agent. ${ }^{50}$ Sidgwick's insight is that ethical theories in which the right has priority over the good are essentially dualist: considerations of an agent's own good remain normative even as reason demands fulfilment of moral obligations. Whereas for the ancients, happiness is the supreme aim of any rational agent, moderns can regard as rational the pursuit of aims different from or even incompatible with one's own good (Sidgwick 1981: 91-92). The opposition between pre-modern and modern ethics thus manifests itself, on Sidgwick's reconstruction, in contrasting accounts of the normativity of ethical obligation: pre-moderns characteristically grounded the latter in the agent's own happiness, while modern moral obligations are non-eudaimonist.

Abizadeh has recently argued that Hobbes's ethics contains both dimensions of normativity. The laws of nature oblige in a eudaimonist sense: in prescribing socially necessary means for peace and self-preservation, natural law offers prudential reasons that appeal to the individual's own good. ${ }^{51}$ These laws are hence not moral norms in today's parlance: they neither require impartially taking others' interests into account, nor can individuals be held accountable for living up to these norms (Abizadeh 2018a: 22). The modern juridical conception of moral obligations owed to others is nonetheless present, Abizadeh contends, in Hobbes's ethics. Obligations of justice, incurred by transferring or renouncing rights, are directed to another person to whom the obligee is accountable. Following Stephen Darwall, Abizadeh takes modern moral obligations to be essentially second-personal: others have the normative standing to hold us accountable for conforming to such obligations. ${ }^{52}$ On Abizadeh's reading of Hobbes, culpable failures to fulfil directed

\footnotetext{
49 Also Sidgwick (1988: 6-10). For a helpful gloss on the quoted passage, see Frankena (1992: 176177). Interpretations of Sidgwick's dualism of practical reason are many and varied (e.g. Frankena 1974; McLeod 2000; Crisp 2015: 227-234).

50 As Kant wrote, "it is... the moral law that first determines and makes possible the concept of the good" (1996: 191).

51 For another eudaimonist reading of Hobbes on natural law, developed against an Aristotelian background, see Rutherford (2003, 2012: 194-211).

52 Abizadeh (2018a: 1-5) also follows Darwall in singling out Hugo Grotius as having pioneered a modern juridical conception of ethics. "With Grotius, on the other hand, we get the beginnings of the modern conception of morality as a body of universal norms whose claim on us is fundamentally independent of that of our own good, indeed, that can conflict with our good and bind us even so" (Darwall 2006: 223; also Darwall 2012, 2013: 4-7). Sidgwick (1981: 86, 1988: 198) found the so-called modern dualism of
} 
obligations constitute sins of injustice warranting reactive blame. By contrast, we are not accountable to others for complying with reasons of the good, captured in natural law, though others may critically blame us for such sins of imprudence (Abizadeh 2018a: 188-189). Hobbes, Abizadeh concludes, stood at "a watershed in the transition from the ancient, eudaimonist conception of ethics to the modern, juridical conception of morality" (2018b) and helped "lay the foundations for the modern, juridical conception of ethics" (2018a: 276).

This paper has not examined whether that distinctly modern form of ethical normativity is indeed present in Hobbes. It is not implausible to read him as saying that we only ought to keep obligations owed to others because and insofar as doing so is good for us, rather than because we owe it to others. Instead, I would like to conclude by suggesting another possible contribution of Hobbes to the development of the modern distinction between the right and the good. This contribution consists, not in theorizing a second form of ethical normativity ('the right'), but in reconceptualizing the good along narrowly prudentialist lines. That assessment accords with Annas's claim that "the missing element" in ancient eudaimonist ethics is a "purely self-regarding, prudential rationality taken to be distinct from moral rationality and forming a competitor to it" (1995: 243). ${ }^{53}$

More precisely, my concluding suggestion is that Hobbes's reconceptualization of goodness - as evinced in his dismissal of moral goodness-rephrased and rendered more urgent questions about the rationality of moral conduct. ${ }^{54}$ As "the Foole" in Leviathan puts it, if "Reason... dictateth to every man his own good" (L 15.4), then why would it be rational to keep our agreements at all times? The fool's challenge, I have suggested, is so poignant on Hobbes's account because of his hedonism about the good. If, with Hobbes, we hold that all goodness must ultimately be understood in terms of the agent's pleasure, then considerable argument is needed to show that we have prudential reason to be moral. For many of Hobbes's predecessors, the rationality of moral conduct could be demonstrated more easily not only because of their substantive normative views about which actions accord with rational nature, but also because their conceptual scheme included the bonum honestum as a basic form of goodness irreducible to pleasure. They were hence not required, as Hobbes was, to argue that moral conduct is conducive to felicity understood as "living a life with pleasure, i.e. maximum delight" (AW 38.8).

\footnotetext{
Footnote 52 (continued)

practical reason first clearly worked out in Joseph Butler (1692-1752), and anticipated in Samuel Clarke (1675-1729), Shaftesbury (1671-1713), and William Wollaston (1659-1724). Sidgwick discussed Hobbes in (1988: 163-170) without hinting at modern dualism of practical reason. The first edition of the Methods however includes an intriguing remark about Hobbes. Ethics considered as an investigation of the right, rather than of the good, Sidgwick observed, "has been more prominent in English philosophy since Hobbes, in an age of active jural speculation and debate, raised the deepest views of morality in a jural form" (ME $\left.{ }^{1} 2-3\right)$. All later editions delete the remark.

${ }^{53}$ For Annas's views on the character differences between ancient ethics and modern moral philosophy, see Annas (1992, 1993: 4-10, 439-455, 2017). Cf. Irwin (1995: 284-289).

${ }^{54}$ The salience of this question in eighteenth-century ethics is discussed by Moore (2002) and Darwall (2006).
} 
This point can be further brought out by comparing Hobbes's and Epicurus's rival accounts of the evil of wrongdoing. ${ }^{55}$ The two philosophers agreed that moral conduct is of merely instrumental value-but in quite different senses. Epicurus (1994: 31) was adamant that "it is impossible to live pleasantly without living prudently, honourably, and justly" since wrongdoers, anxious to be found out, cannot attain true peace of mind. "Injustice is not a bad thing in its own right, but [only] because of the fear produced by the suspicion that one will not escape the notice of those assigned to punish such actions" (1994: 35). For Epicurus, a happy life requires virtue because of the mental distress vice causes (pangs of conscience, fear of being caught). Hobbes rejected the Epicurean value of ataraxia and hence had to explain the goodness of virtuous conduct differently.

"Moral Philosophy", Hobbes wrote, "is nothing else but the Science of what is Good, and Evill, in the conversation, and Society of man-kind" (L 15.40). Yet in what sense are the actions and dispositions enjoined by natural law good? Natural law neither tracks nor expresses moral goodness. Observing the laws of nature is instead 'profitably good': "all men agree on this, that Peace is Good, and therefore also the way, or means of Peace, which... are Justice, Gratitude, Modesty, Equity, Mercy, \& the rest of the Laws of Nature, are good; that is to say, Morall Vertues; and their contrarie Vices, Evill" (L 15.40). What makes the moral virtues 'virtues' to begin with is their character as socially requisite means to further each agent's good. The laws of nature capture causal relations that, Hobbes asserted, obtain without exception: "Injustice, Ingratitude, Arrogance, Pride, Iniquity, Acception of Persons, and the rest, can never be made lawfull. For it can never be that Warre shall preserve life, and Peace destroy it" (L 15.38). While natural law needs to be acted upon only amidst widespread compliance ( $\mathrm{L}$ 15.36), to fail to adopt peaceful dispositions is always contrary to reason. It bears noting that peace is necessary, not just for survival, but also for a "contented life" (L 17.1; also e.g. L 30.1). Felicity consists in having "assure[d] for ever, the way of his future desire" (L 11.1). Such assurance is needed since anticipatory pleasures presuppose the confidence that we possess the power to obtain what we desire (EL 8.3). Absent peace, individuals cannot reasonably hope to secure external goods "by their Industry" (L 13.14). "The power and means to live well" are thus found only within the civil state (L 11.2). As for him the laws of nature are merely profitably good, by dint of conducing to peace, Hobbes direly needed this somewhat implausible empirical assumption about the universal irenic tendencies of moral conduct to render natural law immutably 'good'. No such roundabout justification for the goodness of virtue had been needed had he endorsed the traditional view that virtue is its own reward.

This brings me to the upshot of my analysis. How hard it is to prove the rationality of acting morally depends, not just on how we conceive of the right, but also on how we conceptualize the good. What good would it do to act morally? Hobbes is commonly thought to have raised this question so starkly because of his general insensitivity to the demands of justice. I have suggested that the salience of

55 For an argument that Hobbes's reply to the fool is of Epicurean inspiration, see Springborg (2010). 
this question may also, or rather, have been due to his restrictive conception of the good. $^{56}$

Acknowledgements This research has been supported by a senior postdoctoral fellowship from the Research Foundation (FWO)-Flanders under grant \#12L5718N.

Open Access This article is licensed under a Creative Commons Attribution 4.0 International License, which permits use, sharing, adaptation, distribution and reproduction in any medium or format, as long as you give appropriate credit to the original author(s) and the source, provide a link to the Creative Commons licence, and indicate if changes were made. The images or other third party material in this article are included in the article's Creative Commons licence, unless indicated otherwise in a credit line to the material. If material is not included in the article's Creative Commons licence and your intended use is not permitted by statutory regulation or exceeds the permitted use, you will need to obtain permission directly from the copyright holder. To view a copy of this licence, visit http://creativecommons.org/licen ses/by/4.0/.

\section{References}

Abizadeh, Arash. 2018a. Hobbes and the Two Faces of Ethics. Cambridge: Cambridge University Press.

Abizadeh, Arash. 2018b. Online Colloquium (1): Introduction to Hobbes and the Two Faces of Ethics. http://www.europeanhobbessociety.org/general/online-colloquium-1-introduction-to-hobbes-andthe-two-faces-of-ethics/. Accessed 20 Dec 2019.

Ackerman, T.F. 1976. Two Concepts of Moral Goodness in Hobbes's Ethics. Journal of the History of Philosophy 14 (4): 415-425.

Ambrose. 2002. De Officiis, 2 vols. Ed. Ivor J. Davidson. Oxford: Oxford University Press.

Annas, Julia. 1989. Self-Love in Aristotle. Southern Journal of Philosophy 27 (5): 1-18.

Annas, Julia. 1992. Ancient Ethics and Modern Morality. Philosophical Perspectives 6: 119-136.

Annas, Julia. 1993. The Morality of Happiness. Oxford: Oxford University Press.

Annas, Julia. 1995. Prudence and Morality in Ancient and Modern Ethics. Ethics 105 (2): 241-257.

Annas, Julia. 2017. Ancient Eudaimonism and Modern Morality. In The Cambridge Companion to Ancient Ethics, ed. Christopher Bobonich, 265-280. Cambridge: Cambridge University Press.

Aquinas, Thomas. 1912-1936 [1266-1273]. Summa Theologica. Dominican edition, 22 vols, transl. Fathers of the English Dominican Province. London: Burns, Oates and Benziger.

Aristotle. 1926. The 'Art' of Rhetoric, ed. and transl. J.H. Freese. Cambridge: Harvard University Press.

Aristotle. 1960. Topica, ed. and transl. E.S. Forster. Cambridge: Harvard University Press.

Aristotle. 2000. Nicomachean Ethics, ed. and transl. Roger Crisp. Cambridge: Cambridge University Press.

Barnouw, Jeffrey. 2008. Reason as Reckoning: Hobbes's Natural Law as Right Reason. Hobbes Studies 21 (1): 38-62.

Bradley, Ben. 2006. Two Concepts of Intrinsic Value. Ethical Theory and Moral Practice 9 (2): 111-130. Bramhall, John. 1657. Castigations of Mr. Hobbes. London: J. Crook.

Bramhall, John. 1995 [1658]. The Catching of Leviathan, or the Great Whale. In Leviathan: Contemporary Responses to the Political Theory of Thomas Hobbes, ed. G.A.J. Rogers, 115-179. Bristol: Thoemess Press.

Cicero. 1927. Tusculan Disputations, ed. J.E. King. Cambridge: Harvard University Press.

Cicero. 1991. On Duties, ed. M.T. Griffin and E.M. Atkins. Cambridge: Cambridge University Press.

Cicero. 1998. The Republic and The Laws, ed. Niall Rudd. Oxford: Oxford University Press.

Cicero. 2001. On Moral Ends, ed. Julia Annas. Cambridge: Cambridge University Press.

\footnotetext{
${ }^{56}$ Research on this article has benefited tremendously from discussion with audiences at the universities of Ghent, Leuven, Mainz, and Adolfo Ibáñez in Santiago, Chile. I am grateful to Stephen Darwall, Robin Douglass, Heikki Haara, Getty Lustila, Laetitia Ramelet, Laurens van Apeldoorn, and two anonymous referees for this journal for providing me with perceptive written feedback.
} 
Cooper, John M. 1998. Reason and Emotion: Essays on Ancient Moral Psychology and Ethical Theory. Princeton: Princeton University Press.

Crisp, Roger. 2015. The Cosmos of Duty: Henry Sidgwick's Methods of Ethics. Oxford: Clarendon Press.

Cumberland, Richard. 2005 [1672]. A Treatise of the Laws of Nature, ed. Jon Parkin. Indianapolis: Liberty Fund.

Darwall, Stephen. 2006. The Foundations of Morality: Virtue, Law and Obligation. In The Cambridge Companion to Early Modern Philosophy, ed. Donald Rutherford, 221-249. Cambridge: Cambridge University Press.

Darwall, Stephen. 2012. Grotius at the Creation of Modern Moral Philosophy. Archiv für Geschichte der Philosophie 94 (3): 296-325.

Darwall, Stephen. 2013. Morality, Authority, and Law: Essays in Second-Personal Ethics, vol. I. Oxford: Oxford University Press.

Engstrom, Stephen, and Jennifer Whiting (eds.). 1996. Aristotle, Kant, and the Stoics: Rethinking Happiness and Duty. Cambridge: Cambridge University Press.

Fernández-Castañeda, Jaime. 1968. Right Reason in Francis Suarez. The Modern Schoolman 45 (2): $105-122$.

Frankena, W.K. 1974. Sidgwick and the Dualism of Practical Reason. The Monist 58 (3): 449-467.

Frankena, W.K. 1992. Sidgwick and the History of Ethical Dualism. In Essays on Henry Sidgwick, ed. Bart Schultz, 175-198. Cambridge: Cambridge University Press.

Frede, Michael. 1999. On the Stoic Conception of the Good. In Topics in Stoic Philosophy, ed. Katerina Ierodiakonou, 71-94. Oxford: Oxford University Press.

Gassendi, Pierre. 1699. Three Discourses of Happiness, Virtue and Liberty. London: Awnsham and John Churchil.

Gauthier, David. 1982. Three against Justice: The Foole, the Sensible Knave, and the Lydian Shepherd. Midwest Studies in Philosophy 7 (1): 11-29.

Gauthier, David. 2001. Hobbes: The Laws of Nature. Pacific Philosophical Quarterly 82 (3): 258-284.

Greene, Robert A. 2015. Thomas Hobbes and the Term 'Right Reason': Participation to Calculation. History of European Ideas 41 (8): 997-1028.

Grotius, Hugo. 2005 [1625]. The Rights of War and Peace, 3 vols, ed. Richard Tuck. Indianapolis: Liberty Fund.

Haakonssen, Knud. 1996. Natural Law and Moral Philosophy: From Grotius to the Scottish Enlightenment. Cambridge: Cambridge University Press.

Harvey, Martin. 2004. Teasing a Limited Deontological Theory of Morals out of Hobbes. The Philosophical Forum 35 (1): 35-50.

Hobbes, Thomas. 1839-1845. The English Works of Thomas Hobbes of Malmesbury, 11 vols, ed. William Molesworth. London: John Bohn. [Cited as EW].

Hobbes, Thomas. 1969. The Elements of Law, Natural and Politic, second edition, ed. Ferdinand Tönnies. London: Frank Cass. [EL].

Hobbes, Thomas. 1976. Thomas White's De Mundo Examined, ed. H.W. Jones. London: Bradford University Press. [AW].

Hobbes, Thomas. 1991. De Homine. In Man and Citizen, ed. Bernard Gert, 33-85. Indianapolis: Hackett. [DH].

Hobbes, Thomas. 1998. On the Citizen, ed. Richard Tuck, transl. Michael Silverthorne. Cambridge: Cambridge University Press. [DCv].

Hobbes, Thomas. 2005. A Dialogue between a Philosopher and a Student, of the Common Laws of England. In Thomas Hobbes. Writings on Common Law and Hereditary Right, ed. Alan Cromartie and Quentin Skinner, 1-146. Oxford: Clarendon Press. [DPS].

Hobbes, Thomas. 2012a. Leviathan, 3 vols, ed. Noel Malcolm. Oxford: Clarendon Press. [L].

Hobbes, Thomas. 2012b. Latin Leviathan. In Leviathan, 3 vols, ed. Noel Malcolm. Oxford: Clarendon Press. [LL].

Inwood, Brad, and L.P. Gerson (eds.). 1994. The Epicurus Reader: Selected Writings and Testimonia. Indianapolis: Hackett.

Irwin, Terence. 1995. Prudence and Morality in Greek Ethics. Ethics 105 (2): 284-295.

Irwin, Terence. 2003. Stoic Naturalism and its Critics. In The Cambridge Companion to the Stoics, ed. Brad Inwood, 345-364. Cambridge: Cambridge University Press.

Irwin, Terence. 2007. The Development of Ethics, Volume I: From Socrates to the Reformation. Oxford: Oxford University Press. 
Irwin, Terence. 2008. The Development of Ethics, Volume II: From Suarez to Rousseau. Oxford: Oxford University Press.

Irwin, Terence. 2010. The Sense and Reference of Kalon in Aristotle. Classical Philology 105 (4): 381-396.

Irwin, Terence. 2012. Obligation, Rightness, and Natural Law: Suárez and Some Critics. In Interpreting Suárez: Critical Essays, ed. Daniel Schwartz, 142-162. Cambridge: Cambridge University Press.

Kagan, Shelly. 1998. Rethinking Intrinsic Value. The Journal of Ethics 2 (4): 277-297.

Kant, Immanuel. 1996. Practical Philosophy, ed. and transl. M.J. Gregor. Cambridge: Cambridge University Press.

Kavka, G.S. 1983. Right Reason and Natural Law in Hobbes's Ethics. The Monist 66 (1): 120-133.

Korsgaard, C.M. 1983. Two Distinctions in Goodness. The Philosophical Review 92 (2): 169-195.

Kraut, Richard. 2010. What is Intrinsic Goodness? Classical Philology 105 (4): 450-462.

Laertius, Diogenes. 2018. Lives of the Eminent Philosophers, ed. James Miller, transl. Pamela Mensch. Oxford: Oxford University Press.

Larmore, Charles. 1996. The Right and the Good. In The Morals of Modernity, ed. idem, 19-40. Cambridge: Cambridge University Press.

LeBuffe, Michael. 2020. Motivation, Reason, and the Good in On the Citizen. In Hobbes's on the Citizen: A Critical Guide, ed. Robin Douglass and Johan Olsthoorn, 89-107. Cambridge: Cambridge University Press.

Lloyd, S.A. 2009. Morality in the Philosophy of Thomas Hobbes: Cases in the Law of Nature. Cambridge: Cambridge University Press.

Locke, John. 1975 [1689]. An Essay Concerning Human Understanding, ed. P.H. Nidditch. Oxford: Oxford University Press.

Locke, John. 1997. Political Essays, ed. Mark Goldie. Cambridge: Cambridge University Press.

Lukac de Stier, María. 2002. The Notion of Good in Hobbes's System. Hobbes Studies 15 (1): 87-99.

Malcolm, Noel. 2002. Aspects of Hobbes. Oxford: Oxford University Press.

Mandeville, Bernard. 1924. The Fable of the Bees, Vol. 1, ed. F.B. Kaye. Oxford: Clarendon Press.

Markus, R.A. 1967. Augustine. In The Cambridge History of Later Greek and Early Medieval Philosophy, ed. A.H. Armstrong, 341-419. Cambridge: Cambridge University Press.

McLeod, Owen. 2000. What is Sidgwick's Dualism of Practical Reason? Pacific Philosophical Quarterly 81 (3): 273-290.

Moore, James. 2002. Utility and Humanity: The Quest for the Honestum in Cicero, Hutcheson, and Hume. Utilitas 14 (3): 365-386.

Olsthoorn, Johan. 2019. Grotius and Pufendorf. In The Cambridge Companion to Natural Law Ethics, ed. Tom Angier, 51-70. Cambridge: Cambridge University Press.

Pufendorf, Samuel. 1729 [1672]. Of the Law of Nature and Nations, transl. Basil Kennett. London: printed for J. Walthoe et al.

Rabinowicz, Wlodek, and Toni Rønnow-Rasmussen. 2000. A Distinction in Value: Intrinsic and For Its Own Sake. Proceedings of the Aristotelian Society 100 (1): 33-51.

Raylor, Timothy. 2001. Hobbes, Payne, and A Short Tract on First Principles. The Historical Journal 44 (1): 29-58.

Raylor, Timothy. 2018. Philosophy, Rhetoric, and Thomas Hobbes. Oxford: Oxford University Press.

Rogers, Kelly. 1993. Aristotle's Conception of $\tau$ ó $\varkappa \alpha \lambda$ òv. Ancient Philosophy 13 (2): 355-371.

Rutherford, Donald. 2003. In Pursuit of Happiness: Hobbes's New Science of Ethics. Philosophical Topics 31 (1-2): 369-393.

Rutherford, Donald. 2012. The End of Ends? Aristotelian Themes in Early Modern Ethics. In The Reception of Aristotle's Ethics, ed. Jon Miller, 194-221. Cambridge: Cambridge University Press.

Schneewind, J.B. 1987. Pufendorf's Place in the History of Ethics. Synthese 72 (1): 123-155.

Schneewind, J.B. 1998. The Invention of Autonomy: A History of Modern Moral Philosophy. Cambridge: Cambridge University Press.

Schneewind, J.B. (ed.) 2003. Moral Philosophy: From Montaigne to Kant. Cambridge: Cambridge University Press.

Shaftesbury [Anthony Ashley Cooper]. 2000. Characteristics of Men, Manners, Opinions, Times, ed. Lawrence E. Klein. Cambridge: Cambridge University Press.

Sidgwick, Henry. 1981 [1907]. The Methods of Ethics. Indianapolis: Hackett.

Sidgwick, Henry. 1988 [1902]. Outlines of the History of Ethics for English Readers. Indianapolis: Hackett. 
Slote, Michael. 2010. Ancient Ethics and Modern Moral Philosophy. In Essays on the History of Ethics, ed. idem, 38-52. Oxford: Oxford University Press.

Springborg, Patricia. 2010. Hobbes's Fool the Stultus, Grotius, and the Epicurean Tradition. Hobbes Studies 23 (1): 29-53.

Strauss, Leo. 1952. The Political Philosophy of Hobbes: Its Basis and its Genesis. Chicago: University of Chicago Press.

Striker, Gisela. 1996. Essays on Hellenistic Epistemology and Ethics. Cambridge: Cambridge University Press.

Suárez, Francisco. 2015. De Legibus, ac Deo Legislatore. In Suárez: Selections from Three Works, ed. Thomas Pink, 1-752. Indianapolis: Liberty Fund.

Suárez, Francisco. 2016. Disputatio Metaphysica X, sect. 1. Transl. Sydney Penner. https://www.sydne ypenner.ca/su/DM_10_1.pdf. Accessed 20 Dec 2019.

Taylor, A.E. 1938. The Ethical Doctrine of Hobbes. Philosophy 13 (52): 406-424.

Tönnies, Ferdinand (ed.). 1969. Short Tract. In Hobbes: The Elements of Law, Natural and Politic, 193210. London: Barnes \& Noble.

Tsouna-McKirahan, Voula. 2002. Is There an Exception to Greek Eudaemonism? In Le Style de la Pensée, ed. Pierre Pellegrin and Monique Canto, 464-489. Paris: Belles Lettres.

White, N.P. 1992. The Attractive and the Imperative: Sidgwick's View of Greek Ethics. In Essays on Henry Sidgwick, ed. Bart Schultz, 310-330. Cambridge: Cambridge University Press.

Woolf, Ralph. 2004. What Kind of Hedonist was Epicurus? Phronesis 49 (4): 303-322.

Publisher's Note Springer Nature remains neutral with regard to jurisdictional claims in published maps and institutional affiliations. 